\title{
MERCURY ACCUMULATION LEVEL IN MEAT AND ORGANS OF FARM AND GAME ANIMALS
}

\section{POZIOM AKUMULACJI RTĘCI W MIĘSIE ORAZ NARZĄDACH ZWIERZĄT HODOWLANYCH I DZIKICH}

\section{Department of Reproduction and Animal Hygiene, Siedlce University of Natural Sciences} and Humanities, Poland

\begin{abstract}
Streszczenie. Rtęć jest pierwiastkiem, który występując w środowisku w dużym stężeniu, przekraczającym normy, może stanowić poważne zagrożenie dla zdrowia oraz życia zwierząt i ludzi. U człowieka zatrucie rtęcią może prowadzić do m.in. uszkodzenia centralnego układu nerwowego, zaburzeń układu odpornościowego, uszkodzenia nerek, wypadania włosów oraz śmierci. Rtęć, oprócz oddziaływania na zdrowie publiczne, wpływa również na zwierzęta, wywołując u zwierząt gospodarskich i łownych objawy mogące prowadzić do obniżenia płodności, walorów produkcyjnych, a nawet śmierci. Ze względu na możliwość bioakumulacji i biomagnifikacji w łańcuchu troficznym stanowi poważne i globalne zagrożenie dla środowiska naturalnego. Aktualnie głównym źródłem narażenia człowieka oraz zwierząt na jej działanie jest spożywanie zanieczyszczonej żywności oraz wody. Z tego powodu dopuszczalny poziom rtęci w mięsie oraz narządach zwierząt uregulowany jest przepisami krajowymi oraz międzynarodowymi. Celem niniejszej pracy było określenie możliwego ryzyka higieniczno-toksykologicznego związanego z akumulacją rtęci w mięsie i narządach zwierząt hodowlanych oraz dzikich w Polsce. Wyniki niektórych badań nad zawartością rtęci w mięsie i wątrobie zwierząt gospodarskich i dzikich wykazały, że na poziom akumulacji tego pierwiastka w organizmie wpływ mają: gatunek zwierzęcia, jego wiek, środowisko życia oraz dieta. Z przeprowadzonych w Polsce w ciągu ostatnich 10 lat badań wynika, że rtęć w tkankach zwierząt występowała w małych ilościach, a przekroczenie jej dopuszczalnego poziomu było sporadyczne.
\end{abstract}

Key words: mercury, meat, farm animals, game animals, food safely.

Słowa kluczowe: rtęć, mięso, zwierzyna łowna, zwierzęta hodowlane, bezpieczeństwo żywności.

\section{INTRODUCTION}

Mercury ( $\mathrm{Hg}$, lat. hydrargyrum), also known as quicksilver, is a d-block chemical element (transition metal) and is the only metal that maintains liquid state in $20^{\circ} \mathrm{C}$. The Latin name "hydrargyros" was borrowed from Greek and means liquid silver.

Mercury is located in the 12th group of the periodic table (formerly IIB), its atomic number is 80 , standard atomic weight is $200.592 \mathrm{~g} \cdot \mathrm{mol}^{-1}$ and density (in room temperature) is $13.54 \mathrm{~g} \cdot \mathrm{cm}^{-3}$. Mercury forms chemical compounds in two oxidation states: $+\mathrm{I}$ and $+\mathrm{Il}$. Mercury's melting temperature is $-38.7284^{\circ} \mathrm{C}$, while its boiling temperature is $357^{\circ} \mathrm{C}$. There are 7 stable isotopes of Mercury, the most common being ${ }^{202} \mathrm{Hg}(29.86 \%)$.

Corresponding author - Adres do korespondencji: Elżbieta Bombik, Department of Reproduction and Animal Hygiene, Siedlce University of Natural Sciences and Humanities, Bolesława Prusa 14, 08-110 Siedlce, Poland, e-mail: elzbieta.bombik@uph.edu.pl 
Mercury's natural emission sources are: volcanic eruptions, hydrothermal vents, weathering and erosion of mercury minerals, evaporation from land and water surface (Gworek and Rateńska 2009). Mercury forms numerous minerals, such as cinnabar and calomel, and can also be found in pure, native form. Pseudomonas mercury-resistant bacteria strains have the capacity to volatilize inorganic and organic mercury to elemental mercury (Pepi et al. 2011). Despite the fact that most mercury emissions occur naturally, it is the localized anthropogenic sources and locally increased concentrations of this element that cause the most concern and create significant risk for health and life of organisms. Primary anthropogenic sources of mercury are: energy and metal industry, metal smelting, fertilizer and pesticide production and combustion of communal waste. Combustion of fossil fuels is the largest contributor. Mercury is also released to atmosphere from waste batteries and lamps (Gworek and Rateńska 2009). According to Statistics Poland (GUS) total mercury emission for Poland in 2015 was 10.6 tons (Ochrona środowiska 2017). Atmospheric mercury concentration depends on many factors: temperature, volatility of mercury compounds, area size and type (for example: sea, agricultural, forest or urban areas), with a tendency for higher concentration in industrialized areas. Mercury concentration in areas with developed chemical industry usually averages between 60 and $1000 \mathrm{ng} \cdot \mathrm{m}^{-3}$, while around coal power plants between 200 and $1700 \mathrm{ng} \cdot \mathrm{m}^{-3}$.

Natural average concentration of mercury in seas and oceans is $0.005 \mu \mathrm{g} \cdot \mathrm{I}^{-1}$, while for fresh water bodies it is approx. $0.010 \mu \mathrm{g} \cdot \mathrm{I}^{-1}$. Soils contain approx. $0.05-0.3 \mathrm{mg} \cdot \mathrm{kg}^{-1}$ of this element (Kabata-Pendias 1999).

The aim of this study was to establish possible hygine and toxicologic risks related to mercury accumulation in meat and organs of farm and game animals accuired in Poland.

\section{MERCURY'S EFFECT ON ORGANISM}

There is no known role of mercury in living organisms and it is considered highly toxic in all forms. There are three paths for mercury to enter the body: through the digestive system, through inhalation and through skin. Mercury pollution is commonplace due to the variety of its compounds and its high environmental mobility. How toxic is mercury, or its compounds, depends on such factors as: chemical form, intake pathway, dosage and exposure time (Leśniewska et al. 2009). Methylmercury compounds are the most dangerous ones to humans, since they cause central nervous system damage.

Mercury has great affinity for tiole groups, hence its damaging impact of cell membrane (Chmielnicka 1994). By inhibiting microtubule assembly, $\mathrm{Hg}$ destroys the cells cytoskeletal structures. Disruption of microtubule assembly is especially damaging in the nervous system cells and can cause significant development disorders. Methylmercury ( $\mathrm{MeHg}$ ) is a strong neurotoxin, capable of biomagnification in following links of the food chain, especially in the aquatic environment. The concentration of $\mathrm{MeHg}$ in the tissues of fish, aquatic birds and mammals can be up to 100000 times higher than in the surrounding water (Leśniewska et al. 2009). MeHg is mostly demethylated in liver and kidneys, however the efficiency of this process in these organs is between 10 to $70 \%$. The damage done to the central nervous system of adults by $\mathrm{MeHg}$ takes the form of focal lesions, causing: neurodegeneration, damage to parietal and temporal lobe, damage and degeneration of sensory neurons in children it 
damages cortical and subcortical encephalon and cerebellum nuclear layer (Stanisławczyk 2016). By inducing antibodies against organisms own proteins, mercury displays toxic effect on the immune system. The Me induced autoimmune response causes glomerulopathy disease of glomerulus leading to renal damage and failure (Hultman and Hansson-Georgiadis 1999). Other toxic effects of Me include: acute bronchitis and pneumonia, circulatory collapse often leading to death (Langauer-Lewowicka and Zając-Nędza 1997). Acrodynia, also known as Selter's disease, is a mercury poisoning syndrome most common in children, occasionally occurring in adults chronically exposed to the element in their work environment (Sapota and Skrzypińska-Gawrysiak 2010). The disease has several characteristic symptoms, including: pain in hands and feet, desquamation, hair loss, irritation, photophobia, conjunctivitis, cardiac arrhythmia, insomnia, anorexia, hypersalivation and hypotonia (muscle weakness) (Sapota and Skrzypińska-Gawrysiak 2010).

Chronic exposure to $\mathrm{Hg}$ salts and fumes can lead to: convulsions, stomatitis, loss of teeth, gums discoloration, diarrhea, debilitation, headaches, kidney damage, neural damage (Langauer-Lewowicka and Zając-Nędza 1997). Neurotoxic properties of mercury have been widely described and documented (Heinz 1979; Heinz and Hoffman 1998; Whitney and Cristol 2017). The effect this element has on birds and mammals is similar, with such symptoms as: debilitation, central nervous system disorders (impaired coordination, behavior disorders) (Heinz 1979). Mercury poisoning can be a direct or indirect cause of death in birds, decreasing their ability to acquire food and avoid predators. Chronic mercury poisoning in birds can lead to: lower birthrates, lower production qualities (egg laying, embryogenesis, lower hatching rates) (Heinz 1974; Heinz and Hoffman 1998; Whitney and Cristol 2017).

\section{MERCURY ACCUMULATION LEVEL IN MEAT}

Contaminated fodder and water are the main sources of mercury in animal products (Żarski et al. 1994). Maximum levels of mercury in foodstuffs in UE are regulated by appropriate Rozporządzenie Komisji (WE) nr 1881/2006, nr 420/2011, nr 629/2008 and food safety procedures in member states, necessary for compliance with EC, are regulated by national law acts (for Poland - DzU 2006, nr 171, poz. 1225). However, Rozporządzenie Komisji (WE) nr 1881/2006 z dnia 19 grudnia 2006 r. does not specify acceptable levels of mercury in mammal meat, poultry and giblets. This situation led to the Poland's Chief Veterinarian's decision to interpret mercury levels in animal tissues using the national program of chemical contamination in animal foodstuffs as a standard. The aforementioned program allows maximum level of mercury of $0.02 \mathrm{mg} \cdot \mathrm{kg}^{-1}$ fresh weight in mammal meat and poultry, 0.05 $\mathrm{mg} \cdot \mathrm{kg}^{-1} \mathrm{f} . \mathrm{w}$. in livers and $0.50 \mathrm{mg} \cdot \mathrm{kg}^{-1} \mathrm{f} . \mathrm{w}$. in fish.

Studies by various authors, on mercury accumulation in farm and wild animal tissues differ in results (Table 1). The differences may come from varied pollution levels in animals environment, consumed food, trophic level and age of studied animals. (Stężycka et al. 2005; Rudy et al. 2007; Bombik 2010; Duma et al. 2012; Łuczyńska et al. 2016). 
Table 1.Content of mercury in selected animal products [ $\mathrm{mg} \cdot \mathrm{kg}^{-1}$ fresh weight]

Tabela 1. Zawartość rtęci w wybranych produktach zwierzęcych [ $\mathrm{mg} \cdot \mathrm{kg}^{-1}$ świeżej masy]

\begin{tabular}{lccc}
\hline $\begin{array}{c}\text { Type of animal product } \\
\text { Kategoria produktu } \\
\text { zwierzęcego }\end{array}$ & \multicolumn{2}{c}{ Product - Produkt } & Author - Autor \\
\cline { 2 - 3 } & meat - mięso & liver - wątroba & \\
\hline Fish - Ryby & $0.122-0.209$ & $0.105-0.142$ & Stężycka et al. (2005) \\
\hline Horses - Konie & $<0.001$ & $0.003-0.061$ & Rudy et al. (2007) \\
\hline Poultry - Drób & $<0.001-0.001$ & $0.001-0.001$ & Rudy and Znamirowska (2009) \\
\hline Cattle - Bydło & $0.004-0.016$ & $0.0172-0.033$ & Bombik (2010) \\
\hline Sheep - Owce & $0.002-0.006$ & $0.002-0.005$ & Bombik (2010) \\
\hline Cattle - Bydło & $<0.001$ & 0.002 & Szkoda et al. (2011) \\
\hline Pig - Świnie & 0.001 & 0.001 & Szkoda et al. (2011) \\
\hline Poultry - Drób & $<0.001$ & 0.001 & Szkoda et al. (2011) \\
\hline Sheep - Owce & $<0.001$ & 0.003 & Szkoda et al. (2011) \\
\hline Rabbits - Króliki & $<0.001$ & 0.001 & Szkoda et al. (2011) \\
\hline Horses - Konie & $<0.001$ & - & Szkoda et al. (2011) \\
\hline Fish - Ryby & 0.036 & - & Szkoda et al. (2011) \\
\hline Red deer - Jelenie & $0.000-0.001$ & $0.001-0.007$ & Szkoda et al. (2012) \\
\hline Roe deer - Sarny & $0.001-0.004$ & $0.003-0.016$ & Szkoda et al. (2012) \\
\hline Boar - Dziki & $0.005-0.008$ & $0.014-0.037$ & Szkoda et al. (2012) \\
\hline Pig - Śswinie & $0.002-0.013$ & $0.039-0.129$ & Duma et al. (2012) \\
\hline Fish - Ryby & $0.003-0.019$ & - & Duma et al. (2012) \\
\hline
\end{tabular}

A study carried out by Stężycka et al. (2005) has shown that mercury levels in fish. caught in Vistula river between 1998 and 2002. ranged from 0.122 to $0.209 \mathrm{mg} \cdot \mathrm{kg}^{-1} \mathrm{f}$.w. for muscle samples and from 0.105 to $0.142 \mathrm{mg} \cdot \mathrm{kg}^{-1} \mathrm{f} . \mathrm{w}$. for liver samples. Highest levels of mercury were found in asp (Leuciscus aspius) $-0.450 \mathrm{mg} \cdot \mathrm{kg}^{-1} \mathrm{f}$.w. and freshwater bream (Abramis brama) $-0.330 \mathrm{mg} \cdot \mathrm{kg}^{-1} \mathrm{f} . \mathrm{W}$. caught in the vicinity of Włocławek. indicating lingering mercury contamination in Włocławek water reservoir and biomagnification in the following links of the food chain.

A study carried out by Rudy et al. (2007) has shown that mercury levels in horse liver in animals younger than 2 years where. on average. $0.003 \mathrm{mg} \cdot \mathrm{kg}^{-1} \mathrm{f} . \mathrm{m}$. while in horses older than 14 years $-0.061 \mathrm{mg} \cdot \mathrm{kg}^{-1} \mathrm{f} . \mathrm{m}$. exceeding the allowed levels. Authors point out. that mercury accumulates primarily in parenchymal organs and that accumulation levels increase with animals' age. This relation was later confirmed in studies carried out on cattle by Bombik (2010). The latter study also shown that mercury levels are higher in meat and liver of cattle than in sheep.

According to Szkoda et al. (2009). annual evaluation of mercury levels in animal products. carried out in 2008. shown that the levels of this element remained low and did not raise toxicological concerns. Mercury levels in meat were: $0.001 \mathrm{mg} \cdot \mathrm{kg}^{-1} \mathrm{f}$.w. in cattle. swine. poultry and horse and $0.033 \mathrm{mg} \cdot \mathrm{kg}^{-1} \mathrm{f} . \mathrm{m}$. in fish. Mercury levels in liver were: $0.002 \mathrm{mg} \cdot \mathrm{kg}^{-1}$ f.w. in cattle and $0.001 \mathrm{mg} \cdot \mathrm{kg}^{-1} \mathrm{f} . \mathrm{w}$. in swine. poultry and rabbit.

Low levels of mercury in animal products where later confirmed in a study by Szkoda et al. (2011). Authors conluded that animal products posed no risk of mercury poisoning to consumers and that average dietary intake was only a fraction of permitted tolerable weekly intake (PTWI). Rudy and Znamirowska (2009) had similar results in a study on poultry meat. 
Concerning game animals. a study by Szkoda et al. (2012) had shown that $4 \%$ of game animal liver samples exceeded allowed mercury levels. By dwelling and feeding in a certain area the animals were exposed to environmental factors that contributed to bioaccumulation of heavy metals in their tissues.

Duma et al. (2012) had shown that mercury levels in fish were higher than in pork (accursed in Podkarpackie voivodeship) and that mercury levels in predatory fish were higher than in herbivorous fish. This relationship was also described by other authors (Havelková et al. 2008; Svecevicius et al.2014; Łuczyńska et al. 2016).

\section{CONCLUSION}

Studies carried out in Poland in recent years indicate that mercury levels in tissues of wild and farm animals remain low. with sporadic incidents of allowed levels being exceeded. Taking into account that permitted tolerable weekly intake (PTWI) levels are $5 \mu \mathrm{g} \cdot \mathrm{kg}^{-1}$ of body weight for total mercury and $1.6 \mu \mathrm{g} \cdot \mathrm{kg}^{-1}$ of body weight for organic mercury ( $\mathrm{MeHg}$ ). the average consumer is not at risk from dietary mercury intake. However. heavy metal emissions and accumulation in the environment, mercury included. increase bioaccumulation of this xenobiotic in meat and giblets of game animals when compared with farm animals.

\section{REFERENCES}

Bombik E. 2010. Badania nad bioakumulacją metali ciężkich i fluoru u przeżuwaczy w rejonie Pomorza Środkowego [Studies on bioaccumulation of heavy metals and fluorine in ruminants in the Central Pomerania Region]. Rozpr. Nauk. Akad. Podl. 107. [in Polish]

Chmielnicka J. 1994. Metale i metaloidy, w: Toksykologia. Podręcznik dla studentów farmacji. Ed. W. Seńczuk. Warszawa, Wydaw. Lek. PZWL, 301-353. [in Polish]

Duma P., Pawlos M., Rudy M. 2012. Zawartość metali ciężkich w wybranych produktach spożywczych województwa podkarpackiego [Contamination of selected food products by heavy metals in the podkarpackie province]. Bromat. Chem. Toksykol. 45(1). 94-100. [in Polish]

Gworek B., Rateńska J. 2009. Migracja rtęci w układzie powietrze-gleba-roślina [Mercury migration in pat tern air-soil-plant]. Ochr. Środ. Zas. Natur. 41. 614-623. [in Polish]

Havelková M., Dušek L., Némethová D., Poleszczuk G., Svobodová Z. 2008. Comparison of mercury distribution between liver and muscle-A biomonitoring of fish from lightly and heavily contaminated localities. Sensors 8(7), 4095-4109.

Heinz G.H. 1979. Methylmercury: reproductive and behavioral effects on three generations of mallard ducks. J. Wildl. Manage 43(2) 394-401.

Heinz G.H., Hoffman D.J. 1998. Methylmercury chloride and selenomethionine interactions on health and reproduction in mallards. Environ. Toxicol. Chem. 17(2), 139-145.

Hultman P., Hansson-Georgiadis H. 1999. Methyl mercury-induced autoimmunity in mice. Toxicol. Appl. Pharm. 154(3), 203-211.

Kabata-Pendias A., Pendias H. 1999. Biogeochemia pierwiastków śladowych. Warszawa, PWN, 240. [in Polish]

Langauer-Lewowicka H., Zając-Nędza M. 1997. Changes in the nervous system due to occupational metallic mercury poisoning. Neurol. Neuroch. Pol. 31(5), 905-913.

Leśniewska E., Szynkowska M.I., Paryjczak T. 2009. Główne źródła rtęci w organizmach ludzi nie narażonych zawodowo [The main sources of mercury in the bodies of people not exposed professionally]. Rocz. Ochr. Środ. 11(1), 403-419. [in Polish] 
Łuczyńska J., Łuczyński M.J., Paszczyk B., Tońska E. 2016. Concentration of mercury in muscles of predatory and non-predatory fish from lake Pluszne (Poland). J. Vet. Res. 60(1), 43-47.

Ochrona środowiska, www.gus.pl, access: 05.02.2018. [in Polish]

Pepi M., Gaggi C., Bernardini E., Focardi S., Lobianco A., Ruta M., Nicolardi V., Volterrani M., Gasperini S., Trinchera G., Renzi P., Gabellini M., Focardi S. 2011. Mercury-resistant bacterial strains pseudomonas and Psychrobacter spp. Isolated from sediments of Orbetello Lagoon (Italy) and their possible use in bioremediation processes. Inter. Biodeter. Biodegrad. 65, 85-91.

Rozporządzenie Komisji (WE) nr 1881/2006 z dnia 19 grudnia 2006 r. ustalające najwyższe dopuszczalne poziomy niektórych zanieczyszczeń w środkach spożywczych, https://eur-lex. .europa.eu/legal-content/PL/TXT/?uri=CELEX\%3A32006R1881, access: 16.08.2018. [in Polish]

Rozporządzenie Komisji (UE) nr 420/2011 z dnia 29 kwietnia 2011 r. zmieniające rozporządzenie (WE) nr 1881/2006 ustalające najwyższe dopuszczalne poziomy niektórych zanieczyszczeń w środkach spożywczych, https://eur-lex.europa.eu/legal-content/PL/TXT/?uri=celex\%3A32011R0420, access: 16.08.2018. [in Polish]

Rozporządzenie Komisji (WE) nr 629/2008 z dnia 2 lipca 2008 r. zmieniające rozporządzenie (WE) nr 1881/2006 ustalające najwyższe dopuszczalne poziomy niektórych zanieczyszczeń w środkach spożywczych, https://eur-lex.europa.eu/legal-content/PL/TXT/?uri=celex\%3A32008R0629, access: 16.08.2018. [in Polish]

Rudy M., Znamirowska A., Zin M. 2007. Level of accumulation of selected heavy metals in horse tissue as a function of age. Med. Weter. 63(11), 1303-1306.

Rudy M., Znamirowska A. 2009. Level of accumulation of heavy metals in tissues of poultry and chemical composition of meat depending on age of birds. Rocz. Nauk. PTZ 5(3), 115-124.

Sapota A., Skrzypińska-Gawrysiak M. 2010. Pary rtęci i jej związki nieorganiczne [Mercury vapor and its inorganic compounds]. Podst. Met. Oceny Środ. Pracy 3(65), 85-149. [in Polish]

Stanisławczyk B. 2016. Poziom akumulacji arsenu i rtęci $w$ tkankach zwierząt [The level of accumulation of arsenic and mercury in the tissues of animals]. Gosp. Mięs. 9, 34-37. [in Polish]

Stężycka E., Bzdęga J., Pawlikowska K., Siwicki A. 2005. Zawartość rtęci w rybach z Wisły w latach 1998-2002 [Mercury content in fish from the Vistula in the years 1998-2002]. Probl. Hig. Epidemiol. 86, 27-29. [in Polish]

Svecevicius G., Kazlauskiene N., Kesminas V., Staponkus R., Taujanskis E., Sauliute G. 2014. Heavy metal accumulation in fishes of different ecological groups from Kairiai landfill regional aquatic ecosystem, in: Materials of the 9th International Conference Environmental Engineering, Vilnus 22-23.05.2014. Vilnus, Vilnius Gediminas Technical University Press Technika, 1-7.

Szkoda J., Żmudzki J., Nawrocka A., Kmiecik M. 2009. Ocena zawartości pierwiastków toksycznych w żywności pochodzenia zwierzęcego [Evaluation of the content of toxic elements in food of animal origin]. Pam. Puł. 151(1), 355-362. [in Polish]

Szkoda J., Nawrocka A., Kmiecik M., Żmudzki J. 2011. Badania kontrolne pierwiastków toksycznych w żywności pochodzenia zwierzęcego [Control tests of toxic elements in food of animal origin]. Ochr. Środ. Zas. Natur. 48, 475-484. [in Polish]

Szkoda J., Durkalec M., Kolacz R., Opalinski S., Żmudzki J. 2012. Zawartość ołowiu. kadmu i rtęci w tkankach zwierzyny łownej [The content of lead. cadmium and mercury in the tissues of game animals]. Med. Weter. 68(11), 689-692. [in Polish]

Ustawa z dnia 25 sierpnia 2006 r. o bezpieczeństwie żywności i żywienia. DzU z 2006 r., nr 171, poz. 1225. [in Polish]

Whitney M.C., Cristol D.A. 2017. Impacts of sublethal mercury exposure on birds: A detailed review. Rev. Environ. Contam. Toxicol. 244, 113-163.

Żarski T.P., Dębski B., Rokicki E., Piątkowski S., Samek M., Lilek F. 1994. Skażenie rtęcią tkanek saren pochodzących z Górnego Śląska i z północno-wschodnich rejonów Polski [Mercury contamination of deer tissue from Upper Silesia and from the north-eastern regions of Poland]. Med. Weter. 50(8), 377-379. [in Polish] 
Abstract. When present in the environment in large concentration, mercury can pose serious danger to human and animal health and life. Mercury poisoning in human organism can lead to, for example: central nervous system damage, immune system disorders, kidney damage, hair loss and death. Besides its impact on public health, mercury also affects animal production, with a variety of poisoning symptoms in farm and game animals, lower birthrates, reduced production qualities and deaths. Mercury is considered a global threat to the environment, due to its ability to accumulate in living organisms. In modern times the main risks of exposure to mercury for people and animals are: contaminated food products and water. For this reason, mercury levels in animal meat and organs are regulated by national and international legislation. The aim of this study was to establish possible hygine and toxicologic risks related to mercury accumulation in meat and organs of farm and game animals accuired in Poland. Results of several studies on mercury content in meat and liver of farm and game animals have shown that the species of animal. its age, environment and diet can affect mercury accumulation levels. The data collected in Poland during last 10 years in Poland indicates that mercury levels remained low, with sporadic incidents of allowed levels being exceeded. 
